Lidya SW. Revisi Pasal Perzinaan...

\title{
Revisi Pasal Perzinaan dalam Rancangan KUHP: Studi Masalah Perzinaan di Kota Padang dan Jakarta
}

\author{
Lidya Suryani Widayati \\ DPR RI Lantai II Ruang Staf Ahli Gedung Nusantara Jakarta \\ lidyadhi@yahoo.com
}

\begin{abstract}
Sexual intercourse between men and women out of marital relationship indicates the current crisis of morality among people. More than this, the sexual intercourse among youths seems to be increasing as the increase of the cases of sexual transmitted diseases (STD). Considering this, the effort to overcome such deviation through criminalization policy cannot be delayed any longer, for the purpose of overcoming any possible negative impacts and deteriorate of people's behavior.
\end{abstract}

Keywords: penal code bill, Section on adultery

\section{Pendahuluan}

Satu-satunya ketentuan hukum positif yang mengatur tentang perzinaan adalah Pasal 284 Kitab Undang-Undang Hukum Pidana (KUHP). Pasal 284 ayat (1) KUHP menentukan ancaman pidana penjara paling lama 9 bulan terhadap seorang pria yang telah kawin yang melakukan zina, padahal diketahui bahwa Pasal 27 BW berlaku baginya; seorang wanita yang telah kawin yang melakukan zina padahal diketahui bahwa Pasal 27 BW berlaku baginya; seorang pria yang turut serta melakukan perbuatan itu, padahal diketahuinya bahwa yang turut bersalah telah kawin; seorang wanita yang telah kawin yang turut serta melakukan perbuatan itu, padahal diketahui olehnya bahwa yang turut bersalah telah kawin dan Pasal 27 BW berlaku baginya. Dari ketentuan tersebut maka perbuatan yang dapat dikategorikan sebagai perzinaan adalah hubungan seks (persetubuhan) yang dilakukan pasangan bukan 
suami isteri, dimana salah satu pihak atau kedua belah pihak masih terikat dalam ikatan pernikahan dengan orang lain. Dengan demikian apabila laki-laki dan perempuan yang kedua-duanya belum menikah dan melakukan hubungan seks di luar ikatan pernikahan yang sah maka tidak dapat dikategorikan sebagai perzinaan dan tidak dapat dijerat oleh hukum. Dengan kata lain, ketentuan Pasal 284 KUHP, baik secara langsung maupun tidak langsung memberikan peluang kepada persetubuhan di luar nikah antara laki-laki dan perempuan yang masingmasing tidak terikat pernikahan dengan orang lain. Ketentuan tersebut, oleh sebagian masyarakat dinilai bertentangan dengan nilai-nilai agama, adat istiadat, dan kesusilaan.

Berbeda dengan rumusan Pasal 284 KUHP, Pemerintah melakukan revisi terhadap Rancangan KUHP mengenai perzinaan yaitu dalam Pasal 484 Rancangan KUHP. Revisi mengenai perzinaan tersebut sebagai berikut: pertama, revisi terhadap sanksi pidana penjara yaitu yang semula paling lama 9 (sembilan) bulan menjadi paling lama 5 (lima) tahun. Kedua, revisi terhadap pelaku perzinaan yaitu yang semula pelaku perzinaan adalah hanya laki-laki menikah dan perempuan menikah yang melakukan hubungan seks bukan dengan istri atau suaminya maka dalam Rancangan KUHP juga meliputi laki-laki dan perempuan yang masing-masing tidak terikat dalam perkawinan yang sah dengan orang lain.

Revisi terhadap pasal perzinaan tersebut, terutama mengenai pelaku perzinaan atau dengan kata lain kriminalisasi terhadap kegiatan seks (hubungan seks) yang dilakukan oleh laki-laki dan perempuan yang masing-masing tidak terikat dalam perkawinan yang sah dengan orang lain, menjadi bahan perdebatan antara pihak yang pro dan yang kontra. Pihak yang kontra terhadap revisi pasal perzinaan menilai bahwa revisi terhadap pelaku perzinaan terlalu mencampuri dan memasung kehidupan pribadi seseorang. Dalam hal ini negara telah melakukan intervensi kehidupan wilayah pribadi warga negaranya. Revisi terhadap pasal perzinaan dinilai sebagai ketentuan yang melanggar hak asasi manusia, dan karena itu mengancam demokrasi.

Selain itu, pihak yang kontra terhadap revisi Pasal 284 KUHP berpandangan bahwa Rancangan KUHP harus mengedepankan prinsip unifikasi. Rancangan KUHP merupakan kodifikasi hukum yang harus bisa diterima seluruh elemen masyarakat. Kalau ada pasal yang tidak bisa dilaksanakan di suatu daerah, tetapi dilaksanakan di daerah lain, 
maka akan menimbulkan ketidakpastian hukum. ${ }^{1}$

Sedangkan pihak yang pro terhadap revisi Pasal perzinaan menilai bahwa masalah perzinahan muncul dari public demand bukan pribadi atau keluarga, karena public demand, maka diatur dalam UU. Di banyak negara liberal, lazim terdapat hukum yang mengatur kegiatan pribadi. Dalam aktivitas seks, warga tidak boleh melakukan hubungan seks sedarah (incest), warga tidak boleh mengumpulkan foto-foto yang masuk dalam kategori "pornografi anak", warga tidak diizinkan berpoligami, atau kalau menggunakan contoh yang lebih ekstrem: warga tidak boleh melakukan bunuh diri dan warga tidak boleh menjadi pecandu narkotika, kendatipun kedua kegiatan itu bisa dilihat sebagai "kegiatan sadar yang dilakukan orang dewasa dengan akibat yang harus ditanggung oleh orang dewasa itu sendiri". Dengan demikian, intervensi negara terhadap wilayah pribadi tidak pernah diharamkan, bahkan dalam masyarakat liberal yang menjadi kunci adalah alasan. Sebuah kegiatan pribadi yang dipercaya berpotensi menimbulkan efek negatif atau dipandang sebagai sebuah tindakan tidak bermoral, lazim dinyatakan terlarang. ${ }^{2}$

Meskipun perzinaan tampak sebagai kegiatan yang bersifat sangat pribadi, namun pada dasarnya perzinaan adalah kegiatan pribadi yang memiliki dimensi sosial luas. Oleh karena itu, intervensi negara mempunyai landasan kokoh antara lain bahwa salah satu penyebab utama penyebaran HIV dan AIDS adalah hubungan seks di luar nikah. Hubungan seks di luar nikah berpotensi menimbulkan kehamilan remaja, kehamilan di luar pernikahan, aborsi, perceraian, yang terkait pula dengan tumbuhnya pola keluarga dengan orang tua tunggal (single parenthood). ${ }^{3}$

Revisi terhadap pasal perzinaan dalam Rancangan KUHP masih menimbulkan perdebatan antara pihak yang pro dan yang kontra terhadap revisi tersebut. Masalah kriminalisasi atas suatu perbuatan haruslah sesuai dengan politik kriminal yang dianut oleh bangsa Indonesia, yaitu sejauh mana perbuatan tersebut bertentangan atau tidak bertentangan dengan nilai-nilai fundamental yang berlaku dalam masyarakat dan oleh masyarakat dianggap patut atau tidak patut dihukum

\footnotetext{
${ }^{1}$ http:/ / www.kompas.com/kompas-cetak/0310/02/utama/599064.htm, “Tunda Dulu Revisi KUHP Sosialisasikan Dulu ke Publik", Kamis, 02 Oktober 2003, diakses 25 November 2005.

${ }^{2}$ http:/ / www.republika.co.id/koran_detail.asp?id=142610\&kat_id=19 \&kat_id1=\&kat_id2=14 Februari 2006, "Soal Zina dan KUHP”, Sabtu, 11 Oktober 2003, diakses 25 November 2005.

${ }^{3}$ Op.Cit., Soal Zina dan KUHP.
} 
dalam rangka menyelenggarakan kesejahteraan masyarakat. Dalam hal ini revisi terhadap ketentuan mengenai perzinaan pun patut untuk dikaji dengan prinsip kehati-hatian. Bagaimana akibatnya jika suatu perbuatan dijadikan sebagai perbuatan pidana (tindak pidana) sedangkan masyarakat menilai perbuatan tersebut sebagai perbuatan yang patut atau tidak tercela.

Berdasarkan latar belakang tersebut penelitian ini difokuskan pada permasalahan apakah revisi terhadap pasal perzinaan yaitu kriminalisasi terhadap kegiatan seks (hubungan seks) yang dilakukan oleh laki-laki dan perempuan yang masing-masing tidak terikat dalam perkawinan yang sah dengan orang lain telah memenuhi kriteria (dasar pembenaran) dalam melakukan kriminalisasi terhadap suatu perbuatan.

\section{Kebijakan Kriminal dan Kriminalisasi}

Segala usaha yang dilakukan melalui pembentukan undang-undang dan tindakan dari badan-badan resmi, yang bertujuan untuk menegakkan norma-norma pokok dari masyarakat dikenal sebagai suatu kebijakan kriminal dalam arti yang luas. Sedangkan kebijakan kriminal atau politik kriminal (criminal policy) dalam arti sempit diartikan sebagai usaha yang rasionil dari masyarakat untuk menanggulangi kejahatan. ${ }^{4}$

Kebijakan atau upaya penanggulangan kejahatan pada hakikatnya merupakan bagian integral dari upaya perlindungan masyarakat (social defence) dan upaya mencapai kesejahteraan masyarakat (social welfare). Oleh karena itu, dapat dikatakan bahwa tujuan akhir dari kebijakan kriminal ialah "perlindungan masyarakat untuk mencapai kesejahteraan masyarakat". ${ }^{5}$

Sebagai sarana penanggulangan kejahatan, kebijakan kriminal dapat mengejawantah dalam berbagai bentuk. Bentuk pertama berupa usahausaha prevention without punishment (tanpa menggunakan sarana penal). Kedua adalah mendayagunakan usaha-usaha pembentukan opini masyarakat tentang kejahatan dan sosialisasi hukum melalui mass media secara luas. Ketiga adalah menggunakan sarana penal yang sering disebut sistem peradilan pidana (criminal justice system). Dalam hal ini secara luas meliputi pula proses kriminalisasi. ${ }^{6}$

\footnotetext{
${ }^{4}$ Sudarto, Hukum dan Hukum Pidana, Bandung, Alumni, 1981, hlm. 161.

${ }^{5}$ Barda Nawawi Arief, Bunga Rampai Kebijakan Hukum Pidana, Bandung, Citra Aditya Bakti, 2005, hlm. 2.

${ }^{6}$ Muladi dan Barda Nawawi Arief, Bunga Rampai Hukum Pidana, Bandung, Alumni, 1982, hlm 8 .
} 
Kriminalisasi merupakan tindakan atau penetapan penguasa mengenai perbuatan-perbuatan tertentu yang oleh masyarakat atau golongan-golongan masyarakat dianggap sebagai perbuatan yang dapat dipidana menjadi perbuatan pidana $^{7}$ atau proses penetapan suatu perbuatan sebagai perbuatan yang dilarang dan diancam dengan pidana bagi barang siapa yang melanggar larangan tersebut ${ }^{8}$ atau suatu proses penetapan suatu perbuatan yang semula bukan tindak pidana menjadi tindak pidana. Proses ini diakhiri dengan terbentuknya undang-undang dimana perbuatan itu diancam dengan suatu sanksi yang berupa pidana. ${ }^{9}$

Herbert L. Packer mengajukan beberapa kriteria penggunaan hukum pidana sebagai sarana penanggulangan kejahatan, khususnya mengenai perbuatan apa yang sebaiknya diatur oleh hukum pidana, yaitu: tingkah laku yang dilarang adalah kelakuan mencolok yang mengancam masyarakat dalam pandangan banyak orang dan tidak dimaafkan oleh bagian terbesar masyarakat; mengancam tingkah laku dengan sanksi pidana harus konsisten dengan tujuan pemidanaan; penindakan tingkah laku tidak akan dihalangi oleh keinginan masyarakat; tingkah laku boleh jadi selalu menghadapi penegakan bersifat diskriminatif dan berat sebelah; mengatur tingkah laku melalui proses hukum pidana tidak akan menimbulkan ketegangan kualitatif dan kuantitatif yang keras; tidak ada alternatif lain selain sanksi pidana untuk menghadapi tingkah laku yang ada. ${ }^{10}$

Ketika hukum pidana dipilih dan ditetapkan sebagai sarana penanggulangan kejahatan maka ada dua masalah sentral dalam kebijakan kriminal yaitu masalah penentuan : perbuatan apa yang seharusnya dijadikan tindak pidana, dan sanksi apa yang sebaiknya digunakan atau dikenakan kepada si pelanggar. ${ }^{11}$

Kebijakan kriminal juga tidak terlepas dari kebijakan yang lebih luas, yaitu "kebijakan sosial" (social policy) yang terdiri dari "kebijakan/upaya-

\footnotetext{
${ }^{7}$ Soerjono Soekanto, Kriminologi Suatu Pengantar, Jakarta, Ghalia Indonesia, 1981, hlm. 62 .

${ }^{8}$ Suwondo, Himpunan Karya Tentang Hukum Pidana, Yogyakarta, Liberty, 1982, hlm. 61 .

${ }^{9}$ Soedarto, opcit., hlm. 31.

${ }^{10}$ H.L. Packer, The Limit of Criminal Sanction, 1963, hlm. 297.

${ }^{11}$ Muladi dan Barda Nawawi Arief, Teori-Teori dan Kebijakan Pidana, Bandung, Alumni, 1998, hlm. 160.
} 
upaya untuk kesejahteraan social" (social-welfare policy) dan "kebijakan/ upaya-upaya untuk perlindungan masyarakat" (social-defence policy). ${ }^{12}$

Berdasar pendekatan yang berorientasi pada kebijakan sosial tersebut, Sudarto berpendapat bahwa dalam menentukan masalah kriminalisasi, harus diperhatikan hal-hal sebagai berikut:

1. penggunaan hukum pidana harus memperhatikan tujuan pembangunan nasional yaitu mewujudkan masyarakat adil dan makmur yang merata materiil dan spirituil berdasarkan Pancasila. Dalam hal ini penggunaan hukum pidana bertujuan untuk menanggulangi kejahatan dan mengadakan pengugeran terhadap tindakan penanggulangan itu sendiri, demi kesejahteraan dan pengayoman masyarakat.

2. perbuatan yang diusahakan untuk dicegah atau ditanggulangi dengan hukum pidana harus merupakan "perbuatan yang tidak dikehendaki", yaitu perbuatan yang mendatangkan kerugian (materiil dan/atau spirituil) atas warga masyarakat.

3. penggunaan hukum pidana harus pula memperhitungkan prinsip "biaya dan hasil" (cost-benefit principle).

4. penggunaan hukum pidana harus pula memperhatikan kapasitas atau kemampuan daya kerja dari badan-badan penegak hukum, yaitu jangan sampai ada kelampauan beban tugas (overblasting). ${ }^{13}$

Pendekatan yang berorientasi pada kebijakan sosial juga dikemukakan dalam Simposium Pembaharuan Hukum Pidana Nasional pada bulan Agustus 1980 di Semarang. Dalam salah satu laporannya dinyatakan antara lain sebagai berikut: masalah kriminalisasi dan dekriminalisasi atas suatu perbuatan haruslah sesuai dengan politik kriminal yang dianut oleh bangsa Indonesia, yaitu sejauh mana perbuatan tersebut bertentangan dengan nilai-nilai fundamental yang berlaku dalam masyarakat dan oleh masyarakat dianggap patut atau tidak patut dihukum dalam rangka menyelenggarakan kesejahteraan masyarakat. ${ }^{14}$

Khususnya mengenai kriteria kriminalisasi dan dekriminalisasi, laporan simposium itu antara lain menyatakan bahwa untuk menetapkan suatu perbuatan itu sebagai tindak kriminal, perlu memperhatikan kriteria umum sebagai berikut: apakah perbuatan itu tidak disukai atau dibenci

${ }^{12}$ Barda Nawawi Arief, Masalah Penegakan Hukum dan Kebijakan Penanggulangan Kejahatan, Bandung, Citra aditya Bakti, 2001, hlm. 73.

${ }^{13}$ Sudarto dalam Muladi dan Barda Nawawi Arief, Teori-Teori dan Kebijakan Pidana, Bandung, Alumni, 1998, hlm. 161.

${ }^{14}$ Barda Nawawi Arief, Bunga Rampai Kebijakan ..., Op.Cit., hlm. 31. 
oleh masyarakat karena merugikan, atau dapat merugikan, mendatangkan korban atau dapat mendatangkan korban; apakah biaya mengkriminalisasi seimbang dengan hasilnya yang akan dicapai, artinya cost pembuatan undang-undang, pengawasan dan penegakan hukum, serta beban yang dipikul oleh korban, pelaku dan pelaku kejahatan itu sendiri harus seimbang dengan situasi tertib hukum yang akan dicapai; apakah akan makin menambah beban aparat penegak hukum yang tidak seimbang atau nyata-nyata tidak dapat diemban oleh kemampuan yang dimilikinya; apakah perbuatan-perbuatan itu menghambat atau menghalangi cita-cita bangsa, sehingga merupakan bahaya bagi keseluruhan masyarakat. ${ }^{15}$

Di samping kriteria umum, Simposium memandang perlu pula untuk memperhatikan sikap dan pandangan masyarakat mengenai patut tercelanya suatu perbuatan, dengan melakukan penelitian, khususnya yang berhubungan dengan kemajuan teknologi dan perubahan sosial. ${ }^{16}$

Terkait dengan masalah tersebut, Bassiouni mengemukakan bahwa keputusan untuk melakukan kriminalisasi dan dekriminalisasi harus didasarkan pada faktor-faktor kebijakan tertentu yang mempertimbangkan bermacam-macam faktor termasuk: keseimbangan sarana-sarana yang digunakan dalam hubungannya dengan hasil yang dicari atau yang ingin dicapai; analisis biaya terhadap hasil-hasil yang diperoleh dalam hubungannya dengan tujuan-tujuan yang dicari; penilaian atau penaksiran tujuan-tujuan yang dicari itu dalam kaitannya dengan prioritas-prioritas lainnya dalam pengalokasian sumber-sumber tenaga manusia; pengaruh sosial dari kriminalisasi dan dekriminalisasi yang berkenaan dengan (dipandang dari segi) pengaruh-pengaruhnya yang sekunder. ${ }^{17}$

Sedangkan menurut Moeljatno ada tiga kriteria kriminalisasi dan dekriminalisasi dalam proses pembaharuan hukum pidana. Pertama, penetapan suatu perbuatan sebagai perbuatan terlarang (perbuatan pidana) harus sesuai dengan perasaan hukum yang hidup dalam masyarakat. Kedua, apakah ancaman pidana dan penjatuhan pidana itu adalah jalan yang utama untuk mencegah dilanggarnya larangan-larangan tersebut. Ketiga, apakah pemerintah dengan melewati alat-alat negara yang

\footnotetext{
${ }^{15} \mathrm{Ibid}$.

${ }^{16}$ Ibid., hlm. 32

${ }^{17}$ Ibid., hal. 32.
} 
bersangkutan, betul-betul mampu untuk benar-benar melaksanakan ancaman pidana kalau ternyata ada yang melanggar larangan. ${ }^{18}$

Dari beberapa pendapat mengenai masalah penentuan kriminalisasi maka ada beberapa kriteria yang harus diperhatikan dalam menentukan kriminalisasi, yaitu sebagai berikut : perbuatan yang akan dikriminalisasikan adalah perbuatan yang melanggar nilai-nilai yang hidup dalam masyarakat (adat istiadat, kesusilaan dan agama); perbuatan yang akan dikriminalisasikan bersifat anti sosial karena merugikan masyarakat atau menimbulkan kerusakan terhadap masyarakat; kebijakan kriminalisasi harus memperhatikan kapasitas atau kemampuan daya kerja badan-badan penegak hukum; kebijakan kriminalisasi harus memperhatikan fungsi dan tujuan hukum pidana untuk menanggulangi kejahatan.

Keempat kriteria yang harus diperhatikan dalam menentukan kriminalisasi ini akan menjadi pisau analisis terhadap revisi pasal perzinaan dalam Rancangan KUHP yaitu mengenai kriminalisasi terhadap kegiatan seks (hubungan seks) yang dilakukan oleh laki-laki dan perempuan yang masing-masing tidak terikat dalam perkawinan yang sah dengan orang lain.

\section{Kriteria Perzinahan}

Saat ini ketentuan mengenai perzinaan diatur dalam Pasal 284 KUHP. Pasal 284 ayat (1) dan ayat (2) KUHP menentukan mengenai perzinaan sebagai berikut :

(1) Diancam dengan pidana penjara paling lama 9 bulan

1. a. terhadap seorang pria telah kawin yang melakukan gendak, padahal diketahui bahwa Pasal 27 BW berlaku baginya;

b. seorang wanita yang telah kawin yang melakukan gendak, padahal diketahui bahwa pasal 27 BW berlaku baginya.

2. a. seorang pria yang turut serta melakukan perbuatan itu, padahal diketahuinya bahwa yang turut bersalah telah kawin;

b. seorang wanita yang telah kawin yang turut serta melakukan perbuatan itu padahal diketahui olehnya, bahwa yang turut bersalah telah kawin dan Pasal 27 BW berlaku baginya.

(2) Tidak dilakukan penuntutan melainkan atas pengaduan suami/istri yang tercemar, dan bilamana bagi mereka berlaku Pasal 27 BW, dalam

${ }^{18}$ Moeljatno, Azas-Azas Hukum Pidana, Jakarta, PT. Bina Cipta, 1985, hlm. 5. 
tenggang waktu tiga bulan diikuti dengan permintaan bercerai atau pisah meja dan ranjang karena alasan itu juga.

Dari rumusan ketentuan Pasal 284 KUHP tersebut maka unsur-unsur perzinaan adalah sebagai berikut : adanya persyaratan telah kawin; adanya pengaduan dari suami atau isteri yang tercemar; dan si turut serta harus mengetahui bahwa pasangannya terikat perkawinan.

Berdasarkan ketentuan Pasal 284 KUHP, apabila laki-laki dan perempuan yang kedua-duanya belum menikah dan melakukan hubungan seks di luar ikatan pernikahan yang sah maka tidak dapat dikategorikan sebagai perzinaan dan tidak dapat dijerat oleh hukum. Dengan kata lain, ketentuan Pasal 284 KUHP, baik secara langsung maupun tidak langsung memberikan peluang kepada persetubuhan di luar nikah antara laki-laki dan perempuan yang masing-masing tidak terikat pernikahan dengan orang lain.

Berbeda dengan ketentuan Pasal 284 KUHP, revisi terhadap ketentuan Pasal tersebut yaitu dalam Pasal 484 Rancangan KUHP menentukan bahwa kegiatan seks (hubungan seks) yang dilakukan oleh laki-laki dan perempuan yang masing-masing tidak terikat dalam perkawinan yang sah dengan orang lain merupakan perbuatan pidana (perzinaan) dan dengan demikian pelanggaran terhadap perbuatan tersebut dapat dijatuhi pidana.

Pasal 484 Ayat (1) Rancangan KUHP menentukan bahwa dipidana karena zina, dengan pidana penjara paling lama 5 (lima) tahun : a) lakilaki yang berada dalam ikatan perkawinan melakukan persetubuhan dengan perempuan yang bukan isterinya; b) perempuan yang berada dalam ikatan perkawinan melakukan persetubuhan dengan laki-laki yang bukan suaminya; c) laki-laki yang tidak dalam ikatan perkawinan melakukan persetubuhan dengan perempuan, padahal diketahui bahwa perempuan tersebut berada dalam ikatan perkawinan; d) perempuan yang tidak dalam ikatan perkawinan melakukan persetubuhan dengan lakilaki, padahal diketahui bahwa laki-laki tersebut berada dalam ikatan perkawinan; atau e) laki-laki dan perempuan yang masing-masing tidak terikat dalam perkawinan yang sah melakukan persetubuhan. Ayat (2) menentukan bahwa tindak pidana tersebut tidak dilakukan penuntutan kecuali atas pengaduan suami, isteri, atau pihak ketiga yang tercemar. Terhadap pengaduan tersebut tidak berlaku ketentuan mengenai tindak pidana aduan yang diatur dalam Pasal 24, Pasal 25, dan Pasal 27 (Ayat 
(3)). Selanjutnya ayat (3) menentukan bahwa pengaduan dapat ditarik kembali selama pemeriksaan di sidang pengadilan belum dimulai.

Dari ketentuan Pasal 484 Rancangan KUHP tersebut rumusan tindak pidana perzinaan masih digolongkan sebagai delik aduan. Namun terdapat revisi mengenai pelaku perzinaan yaitu tidak hanya bagi lakilaki menikah dan perempuan menikah yang melakukan hubungan seks bukan dengan isteri atau suaminya, melainkan juga laki-laki dan perempuan yang masing-masing tidak terikat dalam perkawinan yang sah dengan orang lain. Dengan demikian, Tim Rancangan KUHP telah melakukan kriminalisasi terhadap suatu perbuatan yaitu kegiatan seks (hubungan seks) yang dilakukan oleh laki-laki dan perempuan yang masing-masing tidak terikat dalam perkawinan yang sah dengan orang lain.

Mengacu kepada pendapat beberapa pakar hukum mengenai kriminalisasi (sebagaimana disebutkan dalam kerangka konsepsional), maka kebijakan kriminalisasi harus mempertimbangkan beberapa kriteria sebagai berikut yaitu: Perbuatan yang akan dikriminalisasikan adalah perbuatan yang melanggar nilai-nilai yang hidup dalam masyarakat (adat istiadat, kesusilaan dan agama); Perbuatan yang akan dikriminalisasikan bersifat anti sosial karena merugikan masyarakat atau menimbulkan kerusakan terhadap masyarakat; Kebijakan kriminalisasi harus memperhatikan kapasitas atau kemampuan daya kerja badan-badan penegak hukum; Kebijakan kriminalisasi harus memperhatikan fungsi dan tujuan hukum pidana untuk menanggulangi kejahatan.

Dengan demikian untuk mengetahui apakah perbuatan hubungan suami istri yang dilakukan oleh laki-laki dan perempuan yang keduanya belum menikah patut untuk dijadikan sebagai perbuatan pidana maka harus diperhatikan empat kriteria dalam kebijakan kriminalisasi sebagai berikut :

\section{Perbuatan yang akan dikriminalisasikan adalah perbuatan yang melanggar nilai-nilai yang hidup dalam masyarakat (adat istiadat, kesusilaan dan agama).}

Mengenai penilaian terhadap perbuatan yang dilakukan oleh lakilaki dan perempuan yang belum menikah tetapi melakukan hubungan seksual sehingga dianggap patut atau tidak patut dipidana dikemukakan oleh beberapa narasumber baik baik di kota Padang maupun Jakarta antara lain dari tokoh agama, tokoh adat, aparat kepolisian dan tokoh 
budaya.

Tuanku Bagindo M. Leter, Pucuk Pimpinan Lembaga Kerapatan Adat Alam Minangkabau (LKAAM) ${ }^{19}$ menyatakan bahwa perzinaan adalah tindakan yang sangat bertentangan dengan ajaran agama, adat dan moral sekaligus melanggar falsafah bangsa dan negara, Pancasila dan UUD 1945. Menurut Leter, setiap perempuan dan laki-laki yang telah baligh/ dewasa melakukan hubungan badan (coitus) tanpa melalui pernikahan/ perkawinan dinilai telah melakukan perzinaan.

Lebih tegas lagi Leter menyatakan bahwa masyarakat yang beradab apalagi seperti Indonesia adalah masyarakat yang religius bukan saja menolak, bahkan mengharamkan perzinaan. Apalagi masyarakat Minangkabau/Sumatera Barat dengan filosofi hidupnya : adat basandi syarak, syarak basandi kitabullah (Alqur'an), bukan saja menolak perzinaan bahkan telah memiliki Perda yang melarang terjadinya perzinaan yaitu Perda Nomor 11 Tahun 2001 tentang Pencegahan dan Pemberantasan Maksiat.

Perda Nomor 11 Tahun 2001 tidak hanya melarang setiap orang, pribadi maupun kelompok untuk melakukan perzinaan (Pasal 5 ayat (1)) bahkan larangan juga terhadap tindakan yang mengarah pada terjadinya perzinaan dan tindakan yang merangsang nafsu birahi yang dilakukan dengan gerakan dan/atau tidak menutupi bagian tubuh yang dilarang oleh norma agama dan adat. Lebih jauh dari hal tersebut, ketentuan Perda juga melarang setiap orang, pribadi maupun kelompok untuk menjadi pelindung dalam bentuk apapun terhadap kegiatan perzinaan, baik oknum aparatur sipil/militer maupun mereka yang memberikan kesempatan untuk perzinaan.

Pendapat yang sama dengan Luter juga dikemukakan oleh Sjarief Mustafa, Kepala Dinas Bina Mental Spiritual dan Kesejahteraan Sosial Provinsi DKI Jakarta. ${ }^{20}$ Menurut Sjarief yang dapat dianggap pelaku perzinaan adalah laki-laki dan perempuan yang melakukan persetubuhan dengan tidak didasari oleh suatu ikatan perkawinan yang syah sesuai dengan ketentuan yang berlaku. Perbuatan tersebut sangat bertentangan dengan hukum baik hukum agama maupun hukum negara. Dalam hal

${ }^{19}$ Drs. H. Tuanku Bagindo M. Leter adalah Pucuk Pimpinan LKAAM. Wawancara dilakukan pada tanggal 20 Juni 2006.

${ }^{20}$ Drs. H.A. Sjarief Mustafa adalah Kepala Dinas Bina Mental Spiritual dan Kesejahteraan Sosial Provinsi DKI Jakarta. Wawancara dilakukan pada tanggal 6 September 2006. 
ini, Jakarta juga telah memiliki Perda yang terkait dengan masalah tersebut yaitu Perda Nomor 11 Tahun 1998 tentang Ketertiban Umum Di Wilayah Provinsi DKI Jakarta.

Selain kedua narasumber tersebut, Tuanku Bgd. Muh, Ketua 5 Bidang Organisasi LKAAM ${ }^{21}$ menyatakan bahwa sanksi adat dan sanksi agama otomatis akan berlaku dalam masyarakat yang beradat dan beragama, sesuai dengan tatanan masyarakat Indonesia yang beradat dan beragama. Namun demikian Negara/Pemerintah sebagai pengayom masyarakat harus mampu membuat UU sebagai hukum positif dalam menindak pelaku zina.

Menurut Muh, karena masyarakat Indonesia mayoritas (85\%) beragama Islam dan dasar negara adalah Pancasila serta tuntutan UUD 1945 maka pelaksanaan hukum Islam dapat dilaksanakan secara demokratis dengan tetap menghormati umat agama non Islam. Hal ini sejalan dengan UU Perkawinan dan Peradilan Agama yang telah berjalan dengan baik, lancar dan cukup efektif.

Terkait dengan pernyataan beberapa narasumber tersebut, Penulis berpendapat bahwa tidak dapat dipungkiri terdapat adanya kaitan antara hukum pidana dengan norma yang hidup dalam masyarakat baik norma agama, adat istiadat dan kesusilaan (moral). Dalam kehidupan bermasyarakat juga harus ada keseimbangan antara kebebasan individu dan masyarakat. Selain itu, jika kita memegang teguh falsafah Pancasila dan UUD 1945 maka perzinaan merupakan suatu kejahatan karena bertentangan dengan sila Ketuhanan Yang Maha Esa sebagaimana ketentuan dalam Pasal 29 UUD 1945. Oleh karena itu produk hukum Indonesia harus disesuaikan dengan filosofi dan jati diri bangsa yang religius dalam menegakkan demokrasi Pancasila yang harmonis dan berkeseimbangan antara rohani dan jasmani, antar manusia dengan Ketuhanan Yang Maha Esa (agama), antara hidup duniawi dan ukhrowi, antara tuntutan spiritual dan material.

Menurut Jimly Asshiddiqie, eratnya hubungan antara agama dan hukum, khususnya hukum pidana yang hendak diperbaharui, dapat dilihat secara filosofis-politis dan juridis. Secara filosofis-politis, eratnya hubungan keduanya dapat dilihat dari perspektif Pancasila yang menurut doktrin ilmu hukum di Indonesia merupakan sumber dari segala sumber hukum. Dalam Pancasila itu sendiri, agama mempunyai posisi yang

${ }^{21}$ Wawancara dilakukan pada tanggal 19 Juni 2006. 
sentral. Di dalamnya, terkandung prinsip yang menempatkan agama dan ke-Tuhanan Yang Maha Esa dalam posisi yang pertama dan utama. Oleh karena itu, tidak dapat tidak, agama juga harus diakui mempunyai posisi yang penting dan utama dalam usaha pembaharuan hukum pidana nasional. ${ }^{22}$

Demikian juga dengan tinjauan yuridis, kedudukan agama dalam konteks hukum dan eratnya hubungan antara keduanya dijamin menurut Pasal 29 Undang-Undang Dasar 1945 yang menyatakan : negara berdasar atas ke Tuhanan yang Maha Esa; dan negara menjamin kemerdekaan tiap-tiap penduduk untuk memeluk agamanya masing-masing dan beribadat menurut agamanya dan kepercayaannya itu. ${ }^{23}$

Kedudukan agama di Indonesia sangat berarti mengingat banyak hal. Secara hipotesis, ini dapat dibuktikan dengan kenyataan bahwa meskipun sistem hukum di Indonesia sangat dipengaruhi oleh pemikiran hukum barat, tetapi falsafah hukum dan budaya hukum Indonesia menuntut watak hukum yang berbeda dari watak hukum barat. Bahkan, secara formil masalah kedudukan agama dalam pemikiran hukum pidana di Indonesia itu juga dapat ditelusuri pada kenyataan adanya Pancasila dimana sila keTuhanan Yang Maha Esa merupakan "prima causa"nya, dan pada adanya tradisi pengundang-undangan di Indonesia dengan kata pembukaan undang-undang "Dengan Rahmat Tuhan Yang Maha Esa". Di samping itu, dalam setiap putusan Hakim terdapat pula kata pembuka yang berbunyi “Atas Dasar Keadilan Berdasarkan Ke-Tuhanan Yang Maha Esa'.

Mannheim, seorang ahli kriminologi Inggris, mencari kaitan antara kejahatan dengan norma agama dan norma adat (custom). Ia menarik kesimpulan bahwa kejahatan memang tidaklah identik dengan perilaku yang menyimpang dari norma agama dan atau norma adat, akan tetapi tidak dapat diingkari adanya hubungan yang erat, dalam arti bahwa norma agama dan norma adat dapat mempengaruhi pembuat undangundang. ${ }^{24}$

Mardjono Reksodiputro melihat bahwa aturan (hukum) pidana yang sejalan atau mendukung aturan moral dapat sangat dipengaruhi oleh

${ }^{22}$ Jimly Asshiddiqie, Pembaharuan Hukum Pidana Indonesia, Bandung, Angkasa, 1996, hlm. 6.

${ }^{23} \mathrm{Ibid}$. hlm. 80 .

${ }^{24}$ Topo Santoso, Seksualitas dan Hukum Pidana, Jakarta, Penerbit Ind-Hill-Co, 1997, 
emosi masyarakat. Aturan-aturan moral rupanya, dalam kenyataan, masih mempunyai pengaruh terhadap hukum pidana. ${ }^{25}$

Pendapat Mannheim, Mardjono Reksodiputro dan Jimly Asshiddiqie tersebut diperkuat oleh Muladi, pakar hukum pidana dan salah satu anggota Tim Penyusun Rancangan KUHP. ${ }^{26}$ Muladi mengemukakan bahwa penyusunan RUU KUHP bersumber dari : hukum adat dan hukum agama; hukum pidana positif yang berkembang setelah kemerdekaan, hukum pidana yang berlaku di berbagai keluarga hukum (Keluarga Hukum Kontinental, Anglo Saxon, Sosialis, Timur Tengah, dan Timur Jauh); berbagai aspirasi sosial dan intelektual yang berkembang dalam berbagai forum curah pendapat baik yang bersifat nasional, regional maupun internasional; dan berbagai instrumen internasional yang dikeluarkan oleh organ dan lembaga internasional baik berupa norma, standar, asas-asas, konvensi dan sebagainya yang tumbuh melalui tahap-tahap enunciative, declarative, prescriptive, enforcement, and criminalization. ${ }^{27}$

Dari berbagai pendapat narasumber dan pandangan para pakar hukum pidana tersebut maka perumusan ketentuan-ketentuan hukum dalam rangka pembaharuan KUHP termasuk di dalamnya pembaharuan terhadap pengaturan kehidupan seksual yang menyimpang, sedapat mungkin mempertimbangkan dan mengakomodasi norma agama, adat istiadat, dan kesusilaan.

\section{Perbuatan yang akan dikriminalisasikan bersifat anti sosial karena merugikan masyarakat atau menimbulkan kerusakan terhadap masyarakat.}

Yuzirwan, Ketua 6 Bidang Hukum Adat dan Pemberdayaan Masyarakat LKAAM ${ }^{28}$ menyatakan bahwa perbuatan yang dilakukan oleh pelaku yang masih bujangan yang melakukan hubungan suami istri adalah perbuatan yang merugikan masyarakat atau lingkungan adat. Apabila tidak diberi sanksi maka pelaku tidak akan jera. Hukum positif

${ }^{25}$ Ibid.

${ }^{26}$ Muladi, Beberapa Catatan Berkaitan Dengan RUU KUHP Baru, Makalah yang disampaikan dalam sosialisasi RUU KUHP, diselenggarakan oleh Departemen Kehakiman dan HAM RI, Hotel Sahid Jakarta, 21 Juli 2004.

${ }^{27}$ Ibid.

${ }^{28}$ Ir. Yuzirwan Rasyid PHd adalah Ketua 6 Bidang Hukum Adat dan Pemberdayaan Masyarakat Lembaga Kerapatan Adat Alam Minangkabau (LKAAM). Wawancara dilakukan pada tanggal 20 Juni 2006. 
harus dibangun dari norma atau komitmen masyarakat adat, oleh karena itu pengaturannya harus memperhatikan adat masyarakat. Jika penjatuhan pidana hanya ditujukan bagi pelaku yang sudah menikah maka tidak sejalan dengan hukum adat. Selama ini dalam hukum Adat Minang, pasangan yang belum menikah dan melakukan hubungan suami istri akan dijatuhkan sanksi adat berupa pengucilan/pengusiran.

Mengenai dampak dari perzinaan juga dikemukakan oleh Leter yang berpendapat bahwa perzinaan bukan saja telah meresahkan namun juga telah mengorbankan dan menghancurkan nilai martabat perempuan Indonesia dan generasi yang akan datang. Selain itu, perzinaan juga mengakibatkan rusaknya moral, sistem pewarisan, kemanusiaan dan peradaban. Apalagi, perbuatan zina sudah dianggap pula salah satu lapangan kerja dengan istilah PSK (Pekerja Seks Komersial). ${ }^{29}$

Perzinaan sebagai perbuatan yang sudah meresahkan masyarakat juga dikemukakan oleh Ahmad Rivai, Ajun Komisaris Besar Polisi di Direktorat Reserse Kriminal Umum Polri Daerah Metro Jaya sehingga perlu diberantas melalui penegakan hukum dan upaya lainnya dalam bentuk sosialisasi/penyadaran pada masyarakat. ${ }^{30}$

Menurut Ahmad Rivai, fenomena sosial di sebagian besar masyarakat Indonesia memaknai hubungan seks antara laki-laki dan perempuan yang tidak terikat dalam lembaga perkawinan disebut sebagai berbuat zina. Fenomena semacam ini identik dengan istilah seks bebas yang telah mulai merebak dan menggejala di masyarakat. Fenomena demikian sudah meresahkan karena seks dianggap sebagai sesuatu yang biasa - sebuah kewajaran - sebagai ekspresi kasih sayang - ekspresi cinta, yang apabila dibiarkan pada gilirannya akan merusak citra bangsa. Hal demikian juga secara langsung mengancam nilai-nilai ketimuran dan kesakralan lembaga perkawinan. Bila tidak diwaspadai sejak dini maka Indonesia akan mungkin mengalami pandemik penyakit menular yang ditularkan melalui hubungan seksual, dan kesakralan hubungan seksualitas yang selama ini hidup di tengah masyarakat dan memudar dan akhirnya menghilang.

Ahmad Rivai menyayangkan fenomena zina (makna sosiologi yang identik dengan istilah umum seks bebas) tersebut tidak terakomodasi

\footnotetext{
${ }^{29}$ Leter tidak setuju dengan istilah PSK, karena perbuatan yang dilakukan tidak termasuk pekerjaan atau profesi.

${ }^{30}$ Ahmad Rivai. N, SH., MM adalah Ajun Komisaris Besar Polisi di Direktorat Reserse Kriminal Umum Polri Daerah Metro Jaya. Wawancara dilakukan pada Agustus 2006.
} 
dalam hukum positif sepanjang seks bebas itu dilakukan oleh orang yang tidak terikat perkawinan sah, atas dasar suka sama suka dan tidak di tempat umum. Sehingga ada kesan “Impunity hukum-kemandulan hukum" di mata masyarakat, yang pada akhirnya mendorong masyarakat menciptakan hukumnya sendiri - yang terkadang justru menghancurkan martabat kemanusiaan (misal pelaku diarak bugil - pelaku dihakimi berlebihan hingga babak belur - dibakar, dll).

Penulis berpendapat bahwa timbulnya tindakan main hakim sendiri oleh warga masyarakat terhadap pelaku perzinaan di beberapa daerah mengindikasikan bahwa, perzinaan semata-mata tidak bersifat pribadi. Pasal 284 KUHP sebagai produk pemerintah kolonial mengandung kelemahan karena mengindahkan nilai agama dan mengesampingkan moral budaya bangsa. Terjadinya tindakan main hakim sendiri merupakan implikasi sosial terhadap kelemahan Pasal 284 KUHP.

Mengenai kemungkinan diterapkannya sanksi kepada pelaku zina, H. Muh $^{31}$ berpendapat bahwa diperlukan adanya sanksi pidana terhadap pelaku zina karena perzinaan sama saja akibatnya dengan perjudian, narkoba dan minuman keras, bahkan lebih parah lagi karena perzinaan akan menimbulkan rusaknya moral dan tatanan masyarakat adat dan agama serta kekerabatan, mengaburkan silsilah keturunan, menimbulkan tipisnya rasa tanggungjawab dan kepedulian sosial serta rasa kasih sayang, sulitnya menentukan warisan, mudahnya terjadi kumpul kebo (free sex) karena tidak ada sanksi pidana.

Demikian pula Muasri, Budayawan di Taman Budaya Sumatera Barat $^{32}$ menyatakan bahwa pada umumnya masyarakat menolak adanya perzinaan karena perzinaan tidak saja merendahkan martabat si pelaku dan keluarganya tetapi juga masyarakat lingkungannya. Dalam masyarakat Minangkabau, perzinaan dianggap sebagai suatu perbuatan yang sangat memalukan baik bagi si pelaku, keluarganya maupun masyarakat lingkungannya. Oleh sebab itu si pelaku harus dibuang sepanjang adat (diusir dari kampung dan tidak dianggap sebagai bagian dari masyarakat setempat, hilang haknya dalam masyarakat).

${ }^{31}$ Tuanku Bgd. H. Muh adalah Ketua 5 Bidang Organisasi di LKAAM. Wawancara dilakukan pada tanggal 20 Juni 2006.

${ }^{32}$ Drs. Muasri Rajo Mudo adalah Budayawan di Taman Budaya Sum-Bar. Wawancara dilakukan pada tanggal 21 Juni 2006. 
Terkait dengan hal tersebut, Pakar hukum pidana, Muladi, menanggapi adanya pendapat yang menginginkan agar kumpul kebo dan persetubuhan antara orang dewasa yang tidak kawin atau fornication diatasi saja dengan hukum adat. Menurut Muladi adanya kecenderungan masyarakat perkotaan yang sekuler untuk menerapkan konsep victimless crimes terhadap delik-delik (perbuatan pidana) kesusilaan sebagaimana yang berlaku di Barat yang melihat korban sebagai korban individual. Namun dalam Konsep Timur konsep korban harus dilihat dalam konteks sosial. Dengan konsep KUHP lama (yang sekarang berlaku), delik zina hanya bisa dikenakan kepada mereka yang salah satunya sudah menikah. KUHP tidak bisa menjerat perzinahan yang dilakukan oleh pasangan muda mudi atas dasar suka sama suka. Tetapi kini, dengan masuknya pasal baru, pasangan muda-mudi tadi bisa dipidana. Tim penyusun memasukkan aturan ini, sebagaimana diakui Muladi, melihat dampak banyaknya muda-mudi yang hamil di luar nikah. ${ }^{33}$

Mengenai banyaknya muda-mudi yang hamil di luar nikah, terdapat angka yang cukup mengagetkan mengenai pelaku aborsi di Gorontalo. Data yang diperoleh Koran Metro, di Rumah Sakit Aloei Saboe (RSAS) Gorontalo, dalam sebulan, yang melakukan aborsi mencapai 5 orang. Menariknya, dari 5 orang tersebut 3 atau 4 diantaranya adalah mahasiswi. Bahkan menurut Dr Maimun Ihsan SpOG, salah seorang dokter spesialis kandungan di RSAS, terkadang 5 orang itu semuanya mahasiswi. Hal ini menunjukkan bahwa angka pelaku aborsi di kalangan mahasiswi cukup besar dibandingkan ibu-ibu yang telah memiliki suami. Menurut Maimun, tindakan aborsi ini merupakan salah satu imbas dari pergaulan bebas. ${ }^{34}$

Demikian pula dr. Ratna Suprapti Samil Bagian Obstetri dan Ginekologi Fakultas Kedokteran Universitas Indonesia R.S. Dr. Tjipto Mangunkusumo Jakarta), dalam tulisannya mengemukakan bahwa ada kebutuhan yang semakin meningkat akan penelitian (research) tentang pendidikan seks dan kegagalan totalnya, yang tampak dari peningkatan jumlah kehamilan yang tidak direncanakan pada wanita-wanita remaja. Kehamilan di luar perkawinan berkurang di golongan usia yang lanjut, tetapi tetap

${ }^{33} \mathrm{http}: / /$ cms.sip.co.id/hukumonline/ detail.asp?id=9233\&cl=Berita, “Islamisasi RUU KUHP Bukan Mau Menerapkan Hukum Islam”, diakses tanggal 25 November 2005.

${ }^{34}$ http:/ / groups.yahoo.com/group/gorontalomaju2020/message/17827, “Mahasiswi Dominasi Aborsi di RSAS “, Kamis, 08 Mei 2008 , diakses tanggal 29 Mei 2008. 
meningkat pada wanita-wanita di bawah usia 20 tahun dan akhir-akhir ini pada golongan usia $14-16$ tahun. ${ }^{35}$

WORLD Health Organization menyebutkan setiap tahun ada sekitar 500 ribu perempuan meninggal dunia karena melahirkan dan lebih dari 65 ribu diantaranya remaja perempuan yang meninggal karena aborsi tidak aman. Kenyataan lain, ada 15 juta perempuan remaja melahirkan anak dan sebagian dari mereka sudah melakukan hubungan seksual sebelum menikah. Selain itu, sekitar 42 juta penduduk dunia saat ini menderita HIV/AIDS dan hampir separuh dari mereka mulai mengidap penyakit itu masih berusia remaja. Dari berbagai data menunjukkan remaja sudah banyak yang melakukan hubungan seksual sebelum berusia 19 tahun. ${ }^{36}$

Tingginya kasus penyakit Human Immunodeficiany Virus/Acquired Immnune Deficiency Syndrome (HIV/AIDS), khususnya pada kelompok umur remaja, salah satu penyebabnya akibat pergaulan bebas. Hasil penelitian di 12 kota di Indonesia termasuk Denpasar menunjukkan 10$31 \%$ remaja yang belum menikah sudah pernah melakukan hubungan seksual. Di kota Denpasar dari 633 pelajar Sekolah Menengah Tingkat Atas (SLTA) yang baru duduk di kelas II, 155 orang atau 23,4\% mempunyai pengalaman hubungan seksual. Mereka terdiri atas putra 27\% dan putri 18\%. Data statistik nasional mengenai penderita HIV/AIDS di Indonesia menunjukkan bahwa sekitar 75\% terjangkit hilangnya kekebalan daya tubuh pada usia remaja. ${ }^{37}$

Selain hasil penelitian tersebut, sebuah penelitian yang dilakukan oleh perusahaan riset Internasional Synovate atas nama DKT Indonesia melakukan penelitian terhadap perilaku seksual remaja berusia 14-24 tahun. Penelitian dilakukan terhadap 450 remaja dari Medan, Jakarta,

${ }^{35}$ (http://www.kalbe.co.id/files/cdk/files/05PerkembanganAbortus010.pdf/ 05PerkembanganAbortus010.html, "Perkembangan dalam pandangan tentang ABORTUS", dr. Ratna Suprapti Samil Bagian Obstetri dan Ginekologi Fakultas Kedokteran Universitas Indonesia R.S. Dr. Tjipto Mangunkusumo Jakarta, diakses 29 Mei 2008)

${ }^{36} \mathrm{http}$ / / www.equator-news.com/berita/index.asp?Berita=Harmoni \&id=40219 Equator Online: Harian reformasi pertama di Kalbar-Minggu, 25 Juli 2004, “Pendidikan Kespro yang Diinginkan Remaja" diakses 29 Mei 2008

${ }^{37}$ http:/ / www.blogger.com/ feeds/3067157981936372396/ posts/default/ 5004490266411515241tag:blogger.com,1999:blog-3067157981936372396.post50044902664115152412007-12-05T03:10:00.00008:002007-12-05T03:13:33.721-08:00, diakses 29 Mei 2008. 
Bandung dan Surabaya. Hasil penelitian tersebut mengungkapkan bahwa $64 \%$ remaja mengakui secara sadar melakukan hubungan seks pranikah dan telah melanggar nilai-nilai dan norma agama. Tetapi, kesadaran itu ternyata tidak mempengaruhi perbuatan dan perilaku seksual mereka. Alasan para remaja melakukan hubungan seksual tersebut adalah karena semua itu terjadi begitu saja tanpa direncanakan. ${ }^{38}$

Fakta mengenai hasil penelitian tersebut sangat menyedihkan dan memprihatinkan. Menurut Penulis, tidak adanya ketentuan yang melarang adanya pergaulan bebas berupa hubungan suami istri antara laki-laki dan perempuan di luar ikatan perkawinan yang sah dapat mengakibatkan terjadinya kehamilan dan pada kondisi ketidaksiapan berumah tangga atau menghindar dari pertanggungjawaban maka sering terjadi aborsi. Pembiaran terhadap perilaku atau perbuatan tersebut akan mendorong pergaulan bebas lebih jauh dalam masyarakat dan bukan mustahil menganggap perbuatan tersebut sebagai hal yang wajar dan modern. Orang tidak perlu menikah untuk melakukan hubungan seks dan kehamilan bisa diatasi dengan melakukan aborsi. Oleh karena itu, permasalahan demikian bisa dicegah, bahkan dieliminir dengan berbagai langkah efektif, salah satunya adalah melarang dengan tegas hubungan suami istri tanpa adanya perkawinan yang sah.

\section{Kebijakan kriminalisasi harus memperhatikan kapasitas atau kemampuan daya kerja badan-badan penegak hukum.}

Terkait dengan aspek ke tiga ini, yaitu kebijakan kriminalisasi harus memperhatikan kapasitas atau kemampuan daya kerja badan-badan penegak hukum, Ratna Batara Munti, Direktur LBH APIK Jakarta, yang tidak setuju dengan revisi pasal perzinaan (Pasal 484 Rancangan KUHP) mempertanyakan siapa yang akan menuntut. Ratna mempertanyakan, apakah kita memiliki begitu banyak aparat yang nantinya akan ditugasi untuk mengawasi satu persatu perilaku setiap individu warga negara? Rumusan tersebut bakal memunculkan persoalan baru yaitu memicu banyaknya praktek pemerasan, pencemaran nama baik, polisi-polisi moral yang melakukan sweeping dengan kekerasan, intervensi kehidupan personal warga negara. Ratna juga berpandangan, apabila perbuatan tersebut dilakukan di depan umum jelas melanggar rasa kesopanan di muka umum, dan bisa dikenakan Pasal 281 KUHP, tetapi bila perbuatan

\footnotetext{
${ }^{38}$ Ibid
} 
tersebut tidak dilakukan di depan umum, bagaimana mengkriminalkannya? ${ }^{39}$

Pertanyaan-pertanyaan tersebut menurut penulis dapat dijawab dengan kenyataan bahwa sesungguhnya tidak ada satu pun maling yang mau mengaku; tidak ada penjahat yang melakukan kejahatan atau pelanggaran yang "berani" terang-terangan melakukan kejahatannya. Selain itu, setiap orang yang disangka atau didakwa melakukan suatu tindak pidana apapun, yang bersangkutan ataupun keluarganya pastilah menanggung rasa malu dan tercemar nama baiknya. Pertanyaannya mengapa untuk masalah yang terkait dengan kebebasan seksuil ini menginginkan adanya perbedaan ? Demikian pula aparat kepolisian tidak akan dengan ceroboh untuk melakukan sweeping (apalagi dengan kekerasan) atau melakukan intervensi ke dalam kehidupan seseorang tanpa adanya alat bukti yang kuat.

Dalam upaya penegakan hukum tidak hanya melibatkan peranan aparat kepolisian, melainkan pula kejaksaan, pengadilan, penasehat hukum, dan lembaga pemasyarakatan. Peranan aparat penegak hukum tersebut terkait dengan tugas dan kewenangannya yang meliputi kegiatan pelaporan atau pengaduan, penyelidikan, penyidikan, penuntutan, pembuktian, penjatuhan vonis dan pemberian sanksi, serta upaya pemasyarakatan kembali terpidana. Tugas dan kewenangan aparat penegak hukum telah diatur dalam Kitab Undang-Undang Hukum Acara Pidana (KUHAP) dan peraturan perundangundangan lainnya yang terkait. Dalam pelaksanaannya, untuk menjamin dan memastikan tegaknya hukum itu, apabila diperlukan, aparat penegak hukum diperkenankan untuk menggunakan upaya paksa.

Mengenai kapasitas atau kemampuan daya kerja aparat penegak hukum dapat ditingkatkan melalui pendidikan, pelatihan, seminar, lokakarya, dan sebagainya. Selain itu, tuntutan publik untuk mewujudkan supremasi di bidang hukum, maka baik melalui Undang-Undang Dasar Negara Republik Indonesia Tahun 1945 maupun peraturan perundangundangan yang ada dibawahnya telah mengamanatkan dibentuknya lembaga pengawasan eksternal lembaga penegak hukum. Saat ini terdapat Komisi Yudisial, Komisi Kejaksaan, Komisi Kepolisian, dan sebagainya. Keberadaan komisi-komisi tersebut diharapkan dapat meningkatkan kualitas kinerja dan sekaligus memperbaiki sistem peradilan.

${ }^{39}$ Ratna Batara Munti, Kritisi Atas Rumusan Perluasan Perzinahan Dalam R-KUHP, Makalah dalam Diskusi di P3DI, Setjen DPR RI, Jakarta, tanggal 19 Mei 2006. 


\section{Kebijakan kriminalisasi harus memperhatikan fungsi dan tujuan hukum pidana untuk menanggulangi kejahatan.}

Sebagaimana narasumber lainnya, Bagindo Fahmi, ${ }^{40}$ setuju dengan adanya revisi terhadap Pasal 284 KUHP. Selain itu, Pemerintah juga perlu mempermudah perizinan/proses pernikahan. Menurut Bagindo, berdasarkan suatu penelitian di Sum-Bar, dari 117 responden remaja, 38\% melakukan free sex. Mereka melakukan itu, bukan karena masalah ekonomi tetapi karena moral mereka yang merosot. Oleh karena itu, disinilah hukum harus berperan.

Selain oleh hukum, kehidupan manusia dalam masyarakat dipedomani oleh moral manusia itu sendiri, agama, kaidah-kaidah susila, kesopanan, adat kebiasaan dan kaidah-kaidah sosial lainnya. Antara hukum dan kaidah-kaidah sosial lainnya ini, terdapat hubungan jalin menjalin yang erat. Adakalanya hukum tidak sesuai atau serasi dengan kaidah-kaidah sosial lainnya itu. Tapi dalam satu hal, hukum berbeda dari kaidah-kaidah sosial lainnya, yaitu bahwa penaatan ketentuan-ketentuannya dapat dipaksakan dengan suatu cara yang teratur. Dalam kaitan dengan fungsi hukum tersebut, Mochtar Kusumaatmadja mengakomodasi konsep Roscoe Pound, yaitu "law as a tool of social engineering". Menurut Mochtar, hukum tidak cukup memiliki fungsi sebagai "alat untuk memelihara ketertiban" dalam masyarakat melainkan juga sebagai "alat pembaruan masyarakat". ${ }^{41}$

Dalam membangun hukum nasional, diutamakan asas-asas yang umum diterima bangsa-bangsa tanpa meninggalkan asas-asas hukum asli atau hukum adat yang masih berlaku dan relevan dengan dunia modern. Secara politis perlu dipertahankan asas-asas yang merupakan pencerminan dari tekad dan aspirasi sebagai bangsa yang mencapai kemerdekaannya dengan perjuangan, yaitu yang terkandung dalam Undang-Undang Dasar 1945 dan Mukadimahnya yang merupakan pencerminan dari Pancasila. ${ }^{42}$

\footnotetext{
${ }^{40}$ Bagindo Fahmi adalah seorang Budayawan Sumatera Barat. Wawancara dilakukan pada tanggal 21 Juni 2006.

${ }^{41}$ Mochtar Kusumaatmadja, Fungsi dan Perkembangan Hukum Dalam Pembangunan Nasional, Bina Cipta, Lembaga Penelitian Hukum dan Kriminologi, Fakultas Hukum Unpad, Tanpa Tahun, hlm. 3-4.

${ }^{42}$ Otje Salman dan Eddy Damian ED, Konsep-Konsep Hukum Dalam Pembangunan, Kumpulan Karya Tulis Mochtar Kusumaatmadja, Bandung: Alumni, 2002, hal. 187.
} 
Sejalan dengan Mochtar Kusumaatmadja, dalam Rancangan KUHP perumusan tujuan pemidanaan (the aim of punishment) bersifat komprehensif-integral dan teleologis, baik yang memperhatikan si pelaku (memasyarakatkan terpidana dan membebaskan dari rasa bersalah) maupun yang bersifat melindungi masyarakat (mencegah dilakukannya tindak pidana demi pengayoman masyarakat) serta mengembalikan harmoni kehidupan sosial (menyelesaikan konflik). Tujuan yang bersifat retributif dianggap implied dalam berbagai tujuan pemidanaan yang multidimensional tersebut. Dalam merumuskan tujuan pemidanaan, aspirasi yang berkembang dalam masyarakat adat bahwa setiap sanksi harus dapat mengembalikan keseimbangan yang terganggu akibat terjadinya pelanggaran hukum (evenwichtverstoring) dan menyelesaikan konflik (conflictoplossing) diadopsi sebagai salah satu tujuan pemidanaan. ${ }^{43}$

Pada kenyataannya hubungan persetubuhan yang dilakukan di luar pernikahan berpotensi menimbulkan kehamilan remaja (kehamilan di luar pernikahan). Dan sebagai tindak lanjut dari keadaan yang sudah terlanjur tersebut orang biasanya melakukan aborsi (pembunuhan) atau tumbuhnya orang tua tunggal atau yang paling baik dari dua alternatif terdahulu adalah melakukan pernikahan. Oleh karena itu, kemajuan zaman yang ditandai oleh kemajuan ilmu pengetahuan dan tehnologi hendaknya tidak membuat orang tua membiarkan anak-anaknya terjerumus dalam pergaulan bebas tanpa batas sehingga tidak peduli anak laki-lakinya menghamili anak gadis orang lain atau dengan ikhlas membiarkan anak gadisnya dihamili terlebih dahulu sebelum dinikahi (bagaimana jika si laki-laki ingkar janji, bukankah dilakukan bersama atas dasar suka sama suka ?).

Terkait dengan tujuan pemidanaan tersebut maka dengan tujuan dan harapan yang sama, agar orang tidak melakukan seks di luar nikah, tidak ada lagi (terutama) remaja yang melakukan aborsi, ataupun orang yang menderita HIV/AIDS dan mencegah kondisi yang lebih buruk lagi maka hukum pidana berfungsi sebagai social engenering.

\section{Penutup}

Seiring dengan kemajuan ilmu pengetahuan dan tehnologi serta melandanya budaya barat yang identik dengan kebebasannya, pergaulan

\footnotetext{
${ }^{43}$ Muladi, Beberapa Catatan ..., Op.Cit.
} 
bebas dalam masyarakat termasuk melakukan hubungan seksual antara laki-laki dan perempuan yang tidak terikat dalam lembaga perkawinan merupakan salah satu bentuk krisis moral yang melanda sebagian masyarakat kita dewasa ini. Bahkan hubungan seks diantara remaja meningkat dengan meningkatnya pula insiden penyakit kelamin. Oleh karena itu, upaya mengatasi perilaku menyimpang tersebut melalui kebijakan kriminalisasi merupakan suatu langkah yang tidak dapat ditunda sebagai upaya untuk mencegah dampak atau akibat yang ditimbulkannya serta mencegah kondisi menjadi lebih buruk lagi.

Berdasarkan kriteria yang harus dipenuhi dalam kebijakan kriminalisasi maka perilaku menyimpang tersebut telah memenuhi kriteria untuk dijadikan sebagai perbuatan pidana. Beberapa kriteria tersebut antara lain adalah sebagai berikut : pertama, perbuatan yang akan dikriminalisasikan adalah perbuatan yang melanggar nilai-nilai yang hidup dalam masyarakat (adat istiadat, kesusilaan dan agama). Revisi pasal perzinaan dalam Rancangan KUHP telah memenuhi dasar pembenaran yang harus dipertimbangkan dalam melakukan kriminalisasi. Revisi pasal perzinaan dalam Rancangan KUHP, tidak hanya karena KUHP merupakan peninggalan kolonial Belanda dan karenanya tidak sesuai dengan pandangan hidup bangsa Indonesia yang merdeka dan berdaulat, revisi terhadap pasal perzinaan juga karena alasan yang bersifat filosofis, sosiologis dan yuridis dengan berlandaskan kepada norma agama, adat istiadat dan kesusilaan masyarakat.

Keinginan atau kesadaran untuk memasukkan nilai-nilai agama maupun adat istiadat dalam KUHP bukanlah suatu yang berlebihan tetapi wajar karena nilai itu adalah ajaran Allah Yang Maha Kuasa (tersebut dalam Mukadimah UUD 1945) dan atas kesadaran ber-Ketuhanan Yang Maha Esa (Pancasila).

Kedua, perbuatan yang akan dikriminalisasikan bersifat anti sosial karena merugikan masyarakat atau menimbulkan kerusakan terhadap masyarakat. Pada kenyataannya perbuatan tersebut sudah menghinggapi remaja sehingga banyak kalangan remaja (bahkan pelajar) yang melakukan aborsi, meningkatnya kuantitas orang yang mengidap penyakit HIV/AIDS, dan sebagainya.

Ketiga, kebijakan kriminalisasi harus memperhatikan kapasitas atau kemampuan daya kerja badan-badan penegak hukum. Kapasitas atau kemampuan daya kerja aparat penegak hukum dapat ditingkatkan melalui pendidikan, pelatihan, seminar, lokakarya, dan sebagainya. Selain 
itu, untuk meningkatkan kualitas kinerja dan sekaligus memperbaiki sistem peradilan, saat ini terdapat Komisi Yudisial, Komisi Kejaksaan, Komisi Kepolisian, dan sebagainya.

Keempat, kebijakan kriminalisasi harus memperhatikan fungsi dan tujuan hukum pidana untuk menanggulangi kejahatan memelihara ketertiban dan sebagai alat pembaruan dalam masyarakat yaitu antara lain mencegah dilakukannya hubungan seksual diluar perkawinan. Terkait dengan hubungan seksual antara laki-laki dan perempuan yang tidak terikat dalam lembaga perkawinan maka tujuan yang paling patut untuk dipertimbangkan adalah mencegah efek negatif lain dari perilaku itu sendiri. Apabila perilaku menyimpang ini tidak segera diatasi maka bukan tidak mungkin semakin banyak orang yang hamil di luar nikah, mempunyai penyakit kelamin, AIDS, dan pada akhirnya merusak moral bangsa.

\section{Daftar Pustaka}

Barda Nawawi Arief, Bunga Rampai Kebijakan Hukum Pidana, Bandung: Citra Aditya Bakti, 1996.

- Masalah Penegakan Hukum dan kebijakan Penanggulangan Kejahatan, Bandung, Citra Aditya Bakti, 2001.

Burhan Ashshofa, Metode Penelitian Hukum, Jakarta: Rineka Cipta,1998.

Jimly Asshiddiqie, Pembaharuan Hukum Pidana Indonesia, Bandung, Angkasa, 1996.

Mochtar Kusumaatmadja, Fungsi dan Perkembangan Hukum dalam Pembangunan Nasional, Bandung: Lembaga Penelitian Hukum dan Kriminologi, Fakultas Hukum-Universitas Padjajaran, Bina Cipta, Tanpa Tahun.

Moeljatno, Fungsi dan Tujuan Hukum Pidana Indonesia, Jakarta: Bina Aksara, 1985.

, Azas-Azas Hukum Pidana, Jakarta, PT. Bina Cipta, 1985.

Muladi dan Barda Nawawi Arief, Teori-Teori dan Kebijakan Pidana, Bandung: Alumni, 1992.

, Bunga Rampai Hukum Pidana, Bandung, Alumni, 1982.

Otje Salman dan Eddy Damian ED, Konsep-Konsep Hukum Dalam

Pembangunan, Kumpulan Karya Tulis Mochtar Kusumaatmadja, Bandung: Alumni, 2002.

Ratna Batara Munti, Kritisi Atas Rumusan Perluasan Perzinahan Dalam R- 
KUHP, Makalah dalam Diskusi di P3DI, Setjen DPR RI, Jakarta, tanggal 19 Mei 2006.

Roeslan Saleh, Dari Lembaran Kepustakaan Hukum Pidana, Jakarta: Sinar Grafika, 1988.

Beberapa Asas-Asas Hukum Pidana Dalam Perspektif, Jakarta: Aksara Baru, 1981.

Ronny Hanitijo Soemitro, Metodologi Penelitian Hukum, Jakarta: Ghalia Indonesia, 1983.

Santoso, Topo, Seksualitas dan Hukum Pidana, Jakarta, Penerbit Ind-HillCo, Cetakan Pertama Juni 1997.

Soedarto, Hukum dan Hukum Pidana, Bandung: Alumni, 1981.

Soerjono Soekanto, Kriminologi Suatu Pengantar, Jakarta: Ghalia Indonesia, Cetakan Pertama, 1981.

Perspektif Teoritis Studi Hukum Dalam Masyarakat, Jakarta, Rajawali, 1985.

Sunaryati Hartono, Penelitian Hukum di Indonesia Pada Akhir Abad ke XX, Cetakan pertama, Bandung: Alumni,1994.

Suwondo, Himpunan Karya Tentang Hukum Pidana, 1982, Yogyakarta : Liberty.

Muladi, Beberapa Catatan Berkaitan Dengan RUU KUHP Baru, Makalah yang disampaikan dalam sosialisasi RUU KUHP, diselenggarakan oleh Departemen Kehakiman dan HAM RI, Hotel Sahid, Jakarta, 21 Juli 2004.

http:/ / www.kompas.com/kompas-cetak/0310/02/utama/599064.htm, Kamis, 02 Oktober 2003, Tunda Dulu Revisi KUHP Sosialisasikan Dulu ke Publik.

http:/ / www.republika.co.id/korandetail.asp?id=142610\&kat_id =19\&kat_id1=\&kat_id2=14 Soal Zina dan KUHP Februari 2006, Sabtu, 11 Oktober 2003.

http:/ / cms.sip.co.id/hukumonline/detail.asp?id=9233\&cl=Berita, "Islamisasi RUU KUHP Bukan Mau Menerapkan Hukum Islam", diakses tanggal 25 November 2005.

http:/ / groups.yahoo.com/group/gorontalomaju2020/message/17827, "Mahasiswi Dominasi Aborsi di RSAS", Kamis, 08 Mei 2008 , diakses tanggal 29 Mei 2008.

(http:/ / www.kalbe.co.id/files/cdk/files/05PerkembanganAbortus010. pdf/05PerkembanganAbortus010.html, "Perkembangan dalam pandangan tentang ABORTUS", dr. Ratna Suprapti Samil Bagian 
Obstetri dan Ginekologi Fakultas Kedokteran Universitas Indonesia R.S. Dr. Tjipto Mangunkusumo Jakarta, diakses 29 Mei 2008)

http:/ / www.equator-news.com/berita/index.asp?Berita=Harmoni\&id $=40219$ Equator Online : Harian reformasi pertama di KalbarMinggu, 25 Juli 2004, "Pendidikan Kespro yang Diinginkan Remaja" diakses 29 Mei 2008

http://www.blogger.com/feeds/3067157981936372396/posts/default/ $5004490266411515241 \mathrm{tag}$ : blogger.com,1999:blog3067157981936372396.post-50044902664115152412007-12-05T03: 10:00.00008:002007-12-05T03:13:33.721-08:00, diakses 29 Mei 2008. 